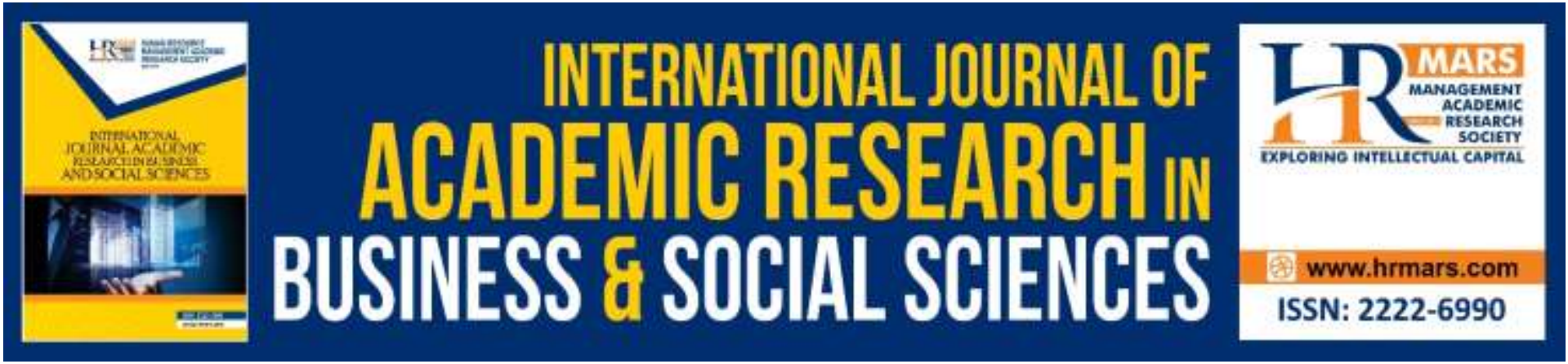

\title{
Management of Risk at The Sungai Sarawak Barrage
}

\section{Goh Chin Guan, Omar Faruqi Marzuki, Yui Pang Hung, Ellie Yi Lih Teo \& Nor Mariah Adam}

To Link this Article: http://dx.doi.org/10.6007/IJARBSS/v11-i17/11401

DOI:10.6007/IJARBSS/v11-i17/11401

Received: 20 August 2021, Revised: 22 September 2021, Accepted: 05 October 2021

Published Online: 25 October 2021

In-Text Citation: (Guan et al., 2021)

To Cite this Article: Guan, G. C., Marzuki, O. F., Hung, Y. P., Teo, E. Y. L., \& Adam, N. M. (2021). Management of Risk at The Sungai Sarawak Barrage. International Journal of Academic Research in Business and Social Sciences, 11(17), 189-206.

\section{Copyright: (c) 2021 The Author(s)}

Published by Human Resource Management Academic Research Society (www.hrmars.com) This article is published under the Creative Commons Attribution (CC BY 4.0) license. Anyone may reproduce, distribute, translate and create derivative works of this article (for both commercial and non-commercial purposes), subject to full attribution to the original publication and authors. The full terms of this license may be seen at: http://creativecommons.org/licences/by/4.0/legalcode

Special Issue Title: Empowering Community and Beyond, iRandau, 2021, Pg. 189 - 206

Full Terms \& Conditions of access and use can be found at http://hrmars.com/index.php/pages/detail/publication-ethics 


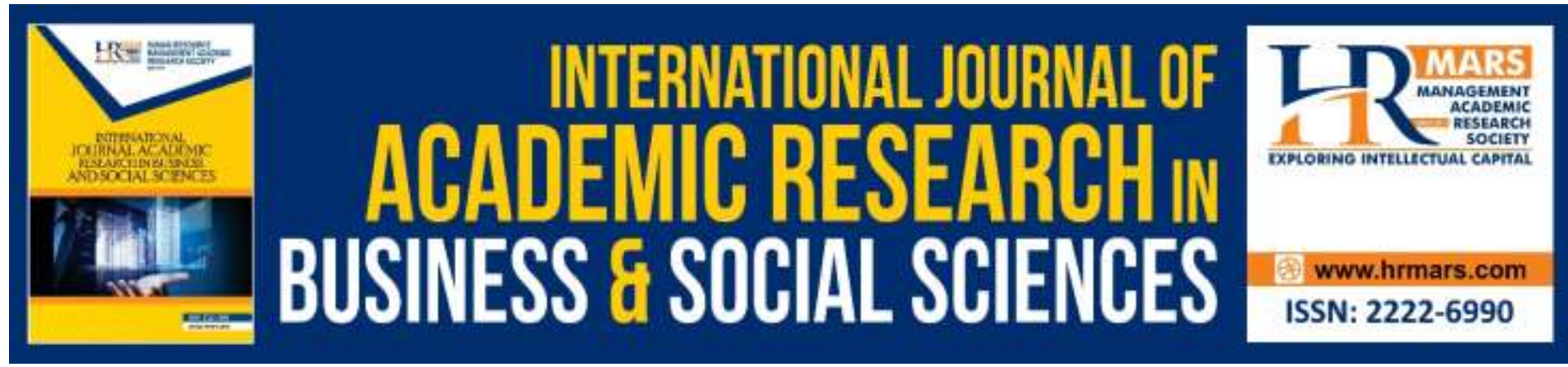

\title{
Management of Risk at The Sungai Sarawak Barrage
}

\author{
Goh Chin Guan ${ }^{1}$, Omar Faruqi Marzuki ${ }^{1,2}$, Yui Pang Hung ${ }^{1}$, \\ Ellie Yi Lih Teo ${ }^{1,2} \&$ Nor Mariah Adam ${ }^{1}$ \\ ${ }^{1}$ Department of Science and Technology, Faculty of Humanities, Management and Science, \\ Bintulu Sarawak Campus, Universiti Putra Malaysia, Bintulu 97008, Sarawak, Malaysia, \\ ${ }^{2}$ Institut Ekosains Borneo (IEB), Universiti Putra Malaysia, Bintulu 97008, Sarawak, Malaysia \\ Email: Capt.goh@sma.edu.my
}

\begin{abstract}
The Sungai Sarawak barrage is part of a novel "three in one" infrastructure in Southeast Asia and is the first of its kind in Malaysia. It consists of five radial barrage gates of $25 \times 12$ meters in dimension with $30 \times 4$ meters piers in between each gate. At the South end of barrage gate 5 is a $120 \times 25$ meters shiplock as shown in Figure 1 . Over these two infrastructures is a $435 \times$ 20 meters, four lane bridges. A combination of such infrastructures is not an ideal concoction as each has its own inherited hazard and operational risk. This project also diverts the natural flow of the Sungai Sarawak, by closing two of its tributaries (Sungai Santubong and Sungai Sarawak) towards a three in one manmade infrastructure. The barrage is operating in a harsh environment with "inherent" risks to the operators, innocent customers, and stakeholders. Diverting a river from its original flow will disturb the riverine regime let alone two river tributaries being closed and diverted through a manmade infrastructure. During the early stages of operation there were many hazards and risks to be identified and the operator had to solve through painful experiences such as near miss accidents, minor accidents, casualty with deaths are some of the lessons learn. This paper shares the teething problems on these risks and how they were solved. mitigated and reduced.
\end{abstract}

Keywords: Infrastructure, Barrage, Shiplock, Bridge, Management of Risk and Operation

\section{Introduction}

Kuching city is located 30 nautical miles (52 kilometers) from the sea. The Sungai Sarawak divides the city into North and South and the sub-urban and urban zones (Mah et al., 2011) are affected by tidal intrusion during the "King Tides". "King Tides" happens during the first four days of the new moon and full moon. The Highest Astronomical Tide (HAT) is 6.5 meters or +2.5 meters above Mean Sea Level (MSL) and is the highest in Southeast Asia (Memon and Murtedza, 1999; Sharp and Lim, 2000). The low-lying areas in the city are affected by the high tidal intrusion during the new moon and full moon which is monthly and fortnightly.

During the onset of the Northeast Monsoon, November to March, locally called "Landas" (Sharp \& Howe, 2000) fluvial flooding could be experience when a daily record of $285 \mathrm{~mm}$ 
(Lim \& Sharp, 2001) or higher is experienced. In 1995, the Sarawak State Government decided to construct the Sungai Sarawak Regulation Scheme (SSRS) which comprises of a barrage, shiplock and bridge over these two infrastructures at the conference of North Junction point and Cameron point as indicated in Figure 1.

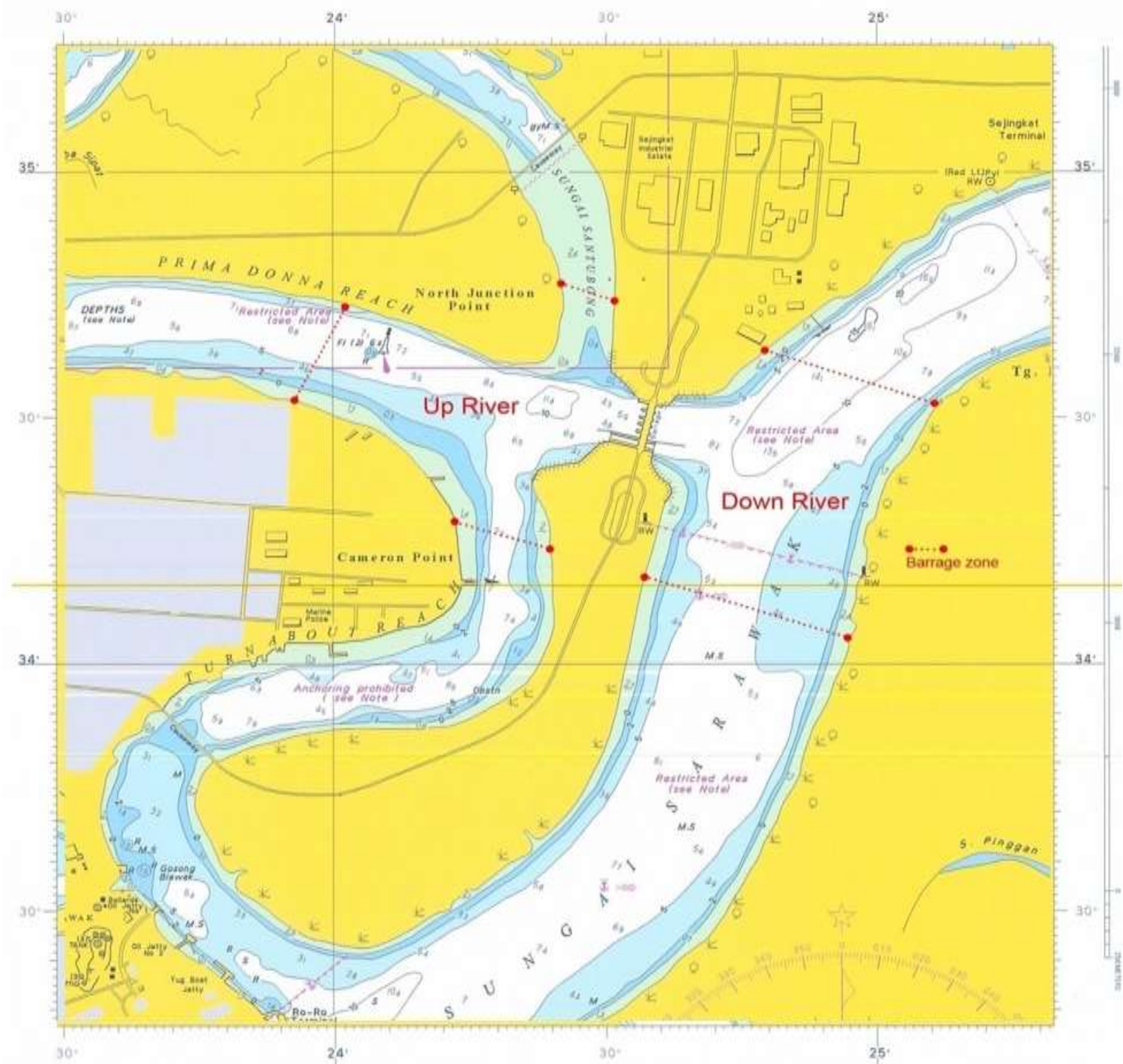

Figure 1: Location of the Sungai Sarawak Regulation Scheme (SSRS) (Abstract from Marine Department Chart number SAR 102)

Besides the main function as a barrage, it also serves as a bridge for the new industrial park at Sijingkat and ship lock for inland navigation. The layout of the three in one infrastructure is in Figure 2. 


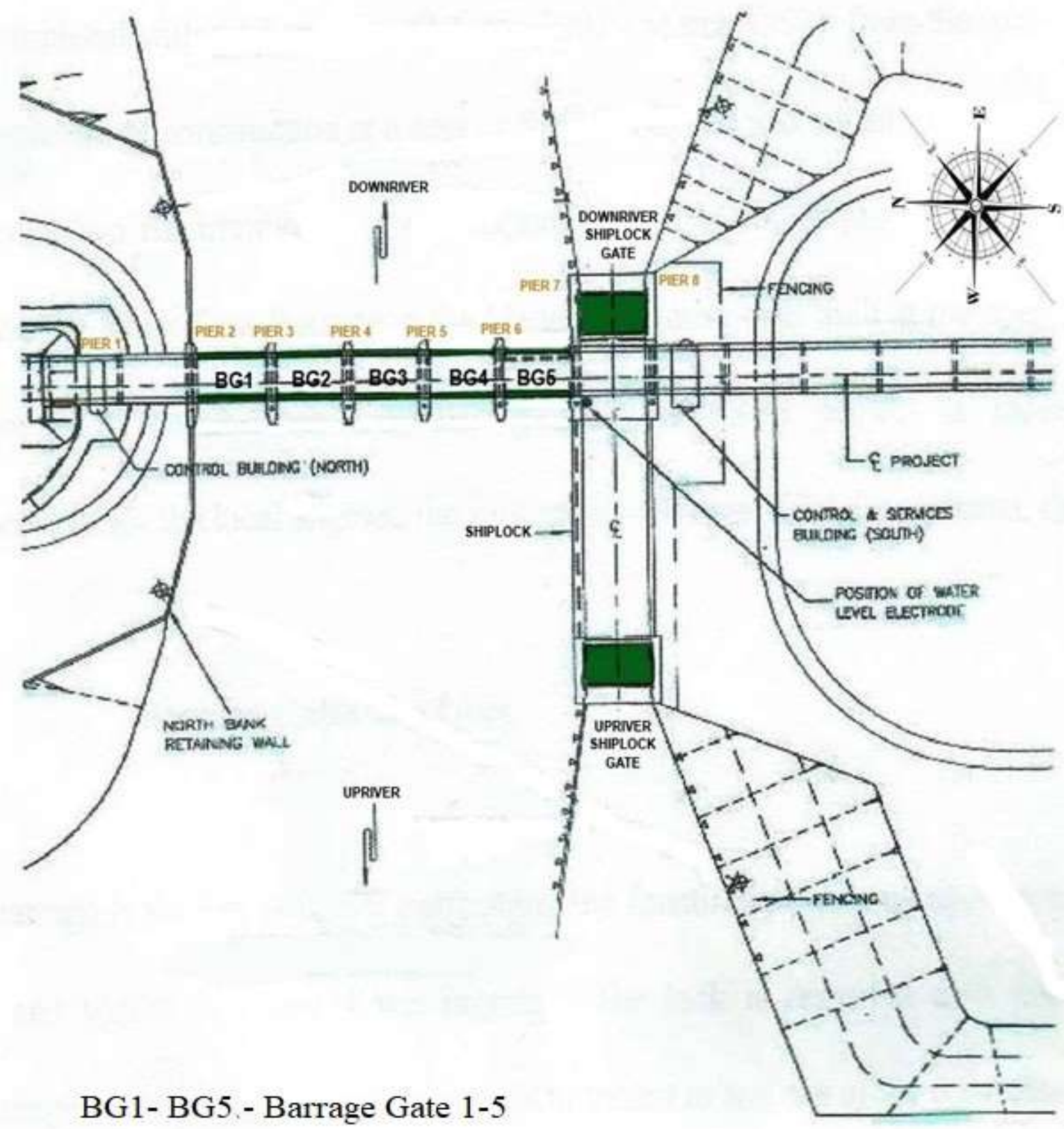

Figure 2: Layout of the Barrage, Shiplock and bridge over these two infrastructures (PPES Works)

The construction of a three in one infrastructure consists of a 435 meters bridge barrage gates and a shiplock, hereby called the Sungai Sarawak Regulation Scheme (SSRS) is located 11 nautical miles (20 kilometers) downriver of the city center. The structure is the property of the State Government under the care of Sarawak Rivers Board (SRB), but the operation and maintenance are managed by a private contractor, Kuching Barrage Management Sdn.Bhd (KBM).

Being a novel project in Malaysia and one of the very first in South East Asia (Kuok et al., 2011) the identification of risk, operational problems and how to reduce and mitigate these risks are the objectives of this study. The Sungai Sarawak Barrage has been in operation 
for 23 years and it is playing a critical role as a center of flood management for the city especially during the "Landas" season (Sharp \& Howe, 2000). The operation team monitors closely the quarterly hourly hydrological data of the river system with its telemetry system to ensure that there is a reservoir for the runoff from the 1430 square kilometers catchment that will accumulate behind the barrage gates when they are closed during the flood tide. The worst scenario of flooding happens when there is a high runoff from the upstream catchment during the Northeast Monsoon coincides with the King Tides from the downstream. The Sungai Sarawak barrage has eliminated the bimonthly tidal intrusion since the birth of the city and is ensuring Kuching city water supply during the drought season.

Since its operation, it functions also as a flood warning center entrusted by the State Government to act first-hand in the case of flood emergency. This paper shares the experience of identifying the risk of operating, managing successful implementation for the last two decades.

\section{Description of the barrage gates 1-4}

The four radial gates $(25 \times 12 \mathrm{~m}$ ) (Darrien, 2012) are supported by hydraulic gate arms on the upstream side of the $25 \times 4 \mathrm{~m}$ pier superstructures as seen on Figure 3 . The gates are designed to be stable under all conditions of load and to eliminate vibrations due to turbulent flow. Desiltation is achieved by raising the gate to a nominal height $(1 \mathrm{~m})$ from the barrage bed and allowing underflow to regulate water level upriver and remove siltation upriver. There are five spillway flaps at each gate to allow discharge from the upriver side to the downriver side when the head difference is more than $50 \mathrm{~mm}$ and to prevent flow in the opposite side. These spillway flaps are $4 \times 3.2 \mathrm{~m}$ hinged and regulated by hydraulic dampers and counterweights as seen in Figure 4 and 5.

When closed, the gates rest on a steel beam in the floor of the barrage sill. Guide shoes attached to the vertical end frames align the gates during operation. The bottom edge of the gate is engaged via rubber compound seals to the steel frame embedded into the barrage sill and the side of the gates is engaged via rubber compound seals to the steel frame embedded in the pier wall. The gates will rise above the water level in the open position as seen in Figure 6. 
INTERNATIONAL JOURNAL OF ACADEMIC RESEARCH IN BUSINESS AND SOCIAL SCIENCES

Vol. 11, No. 17, Empowering Community and Beyond, iRandau, 2021, E-ISSN: 2222-6990 @ 2021 HRMARS

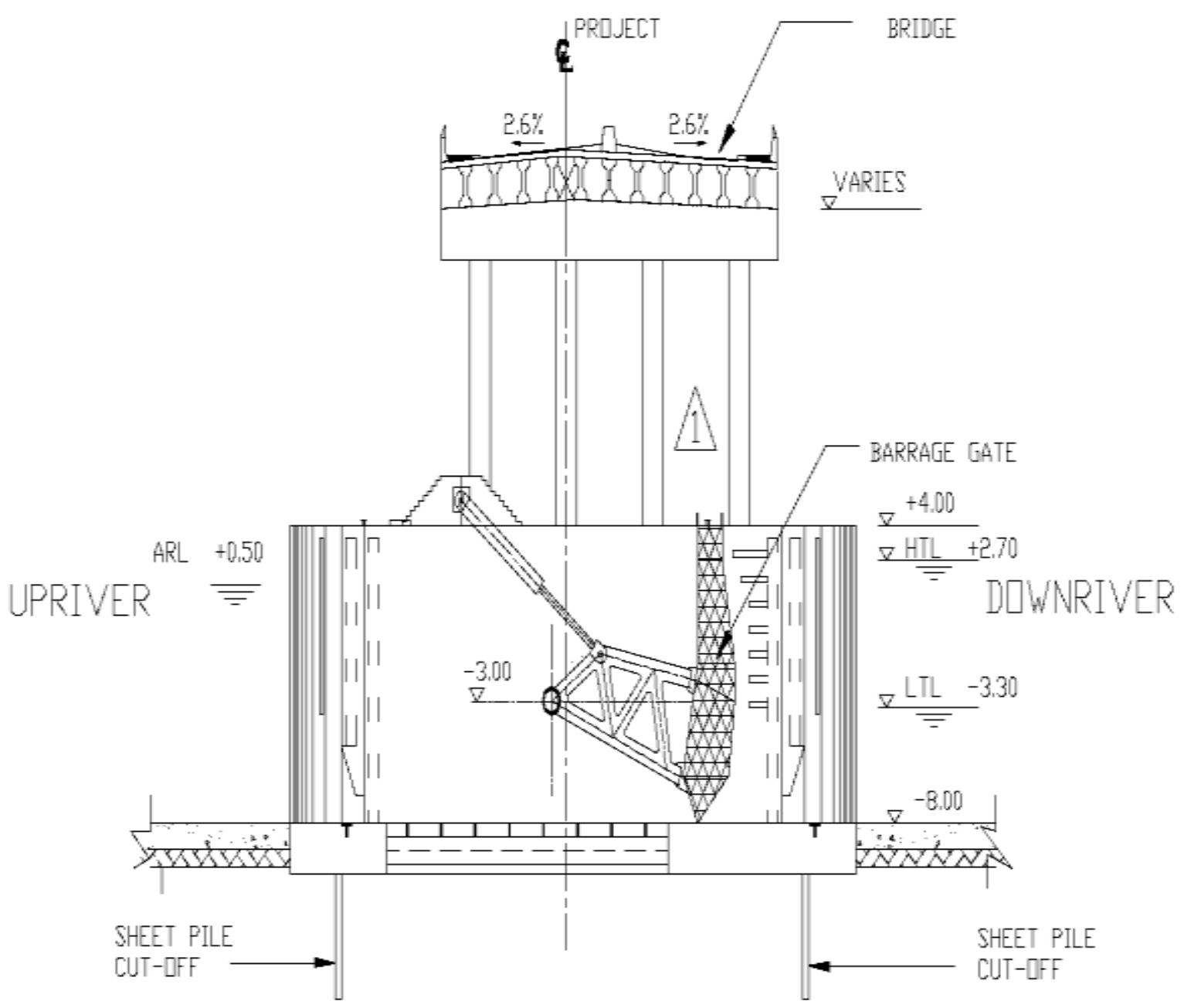

Figure 3: Cross section view of a barrage gate in the close position (PPES Works) 
INTERNATIONAL JOURNAL OF ACADEMIC RESEARCH IN BUSINESS AND SOCIAL SCIENCES

Vol. 11, No. 17, Empowering Community and Beyond, iRandau, 2021, E-ISSN: 2222-6990 @ 2021 HRMARS

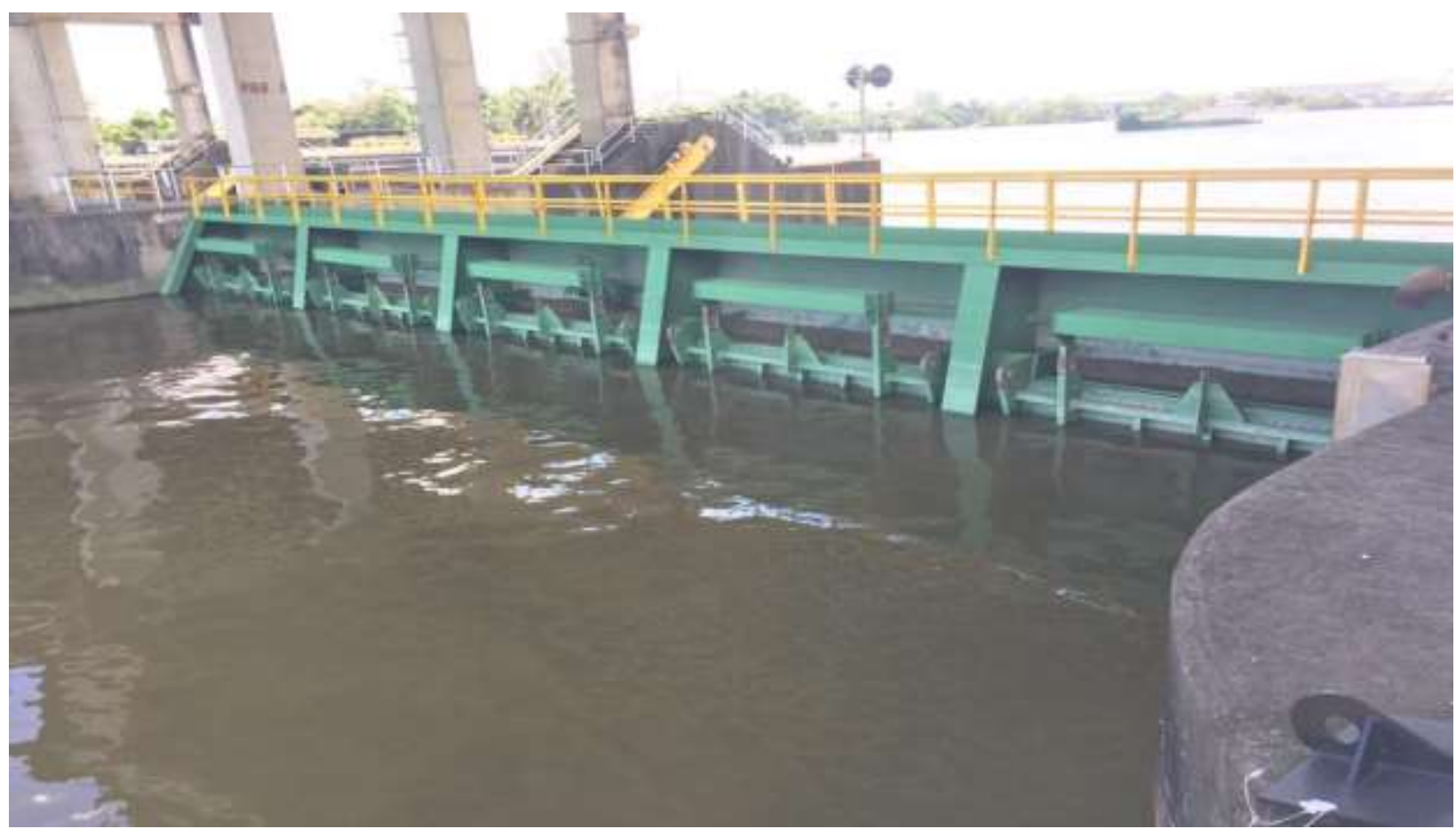

Figure 4: Downriver view of barrage gate 4 spillway flap gates closed when water level downriver is higher than upriver

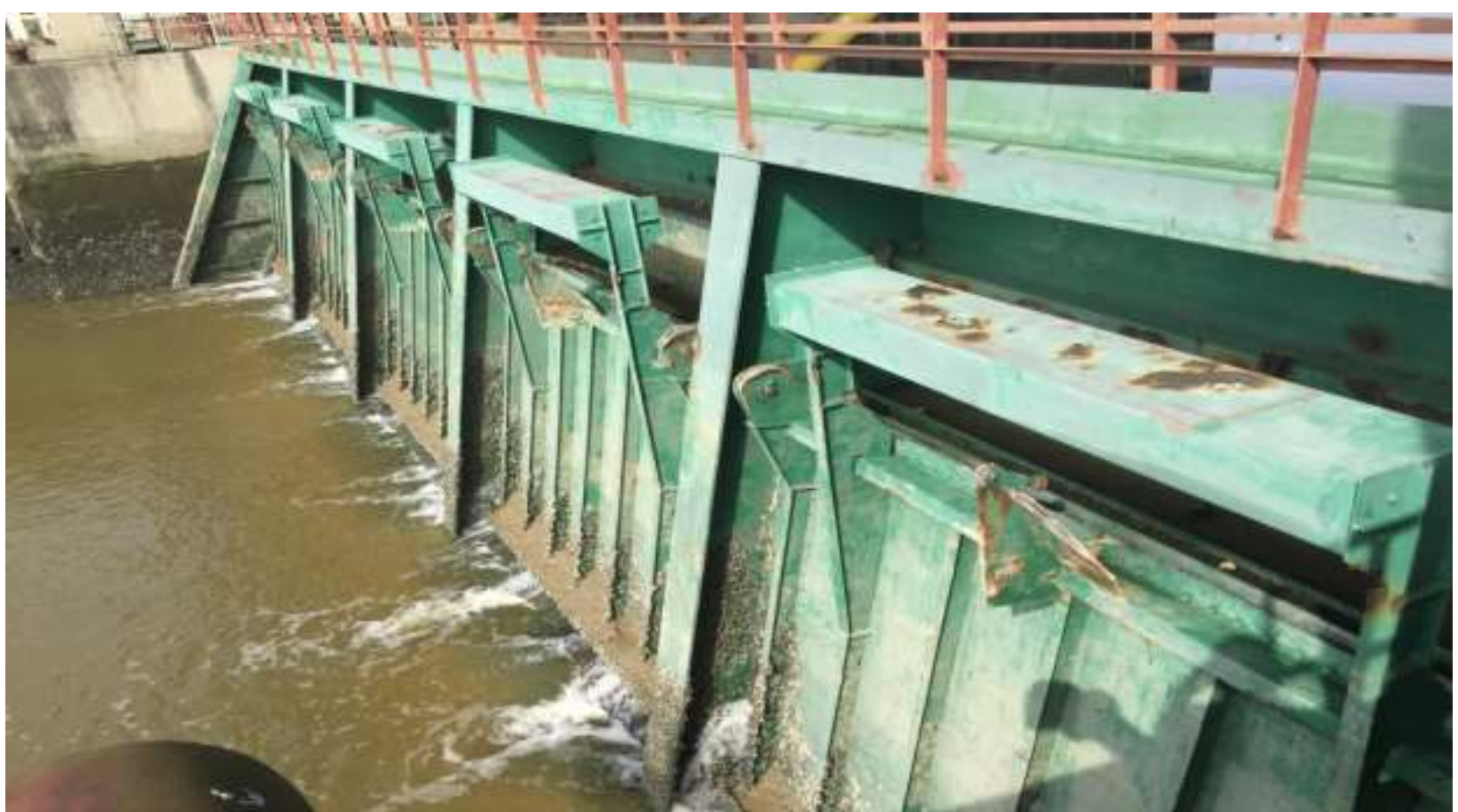

Figure 5: Spillway flap gates locked - pressure from upriver leaking seals taken from downriver 


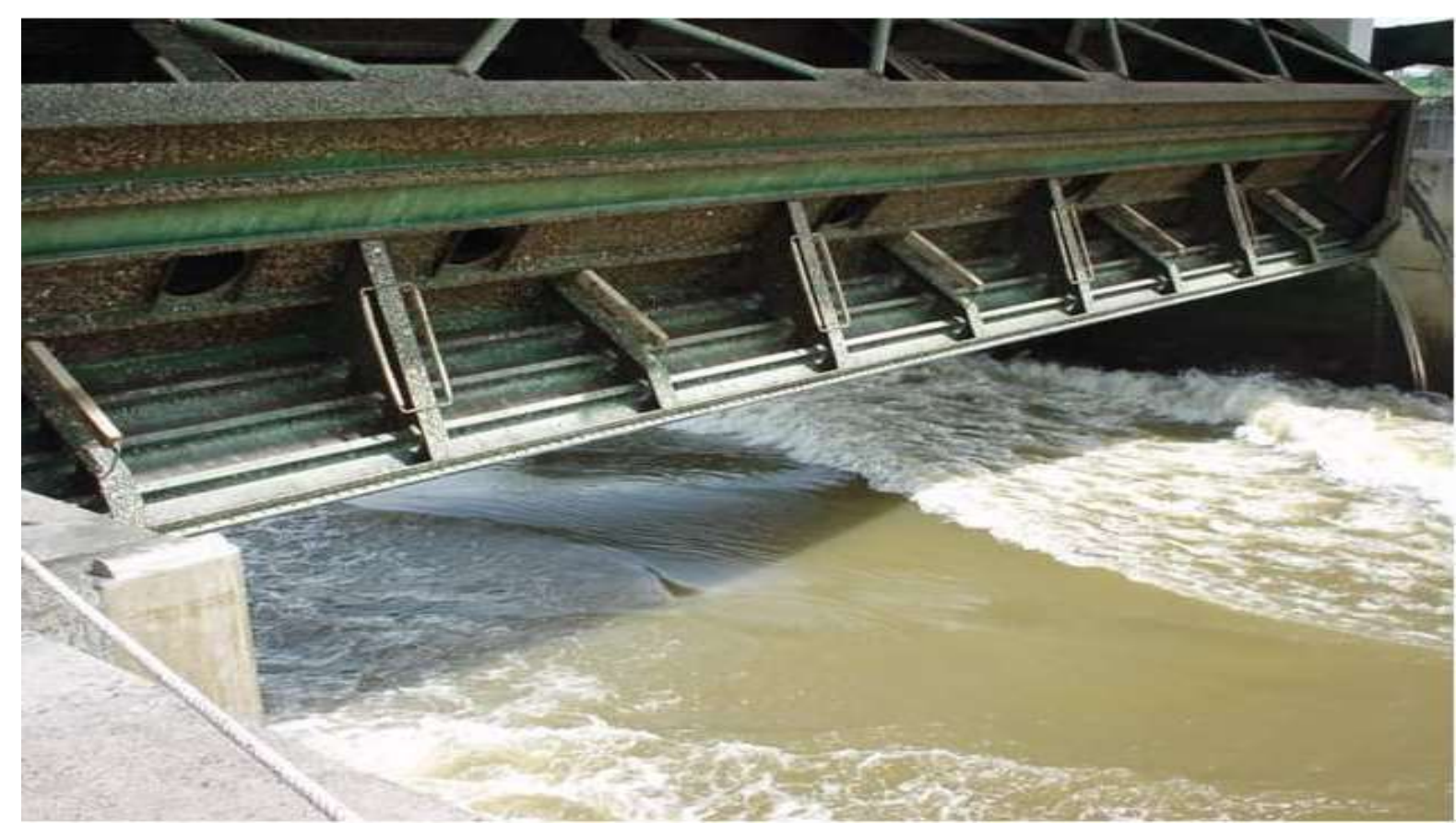

Figure 6: Barrage gate in open position

\section{Description of barrage gate 5}

Barrage gate 5 is an emergency gate and is identical in shape, size, and weight, like the shiplock gates which is interchangeable in times of emergency. It can be used for transit of vessels when the shiplock is closed for repairs however, the window period for transit of vessel is limited to an hour and not all vessels can transit through this gate. When in the open position the gate will be below the water level, lying horizontal at the sill of the gate as shown in red dotted line in Figure 7. Figure 8 illustrates barrage gate 4 and 5 in the open position. Fishing vessel is seen transiting the gate during the safe window period. 


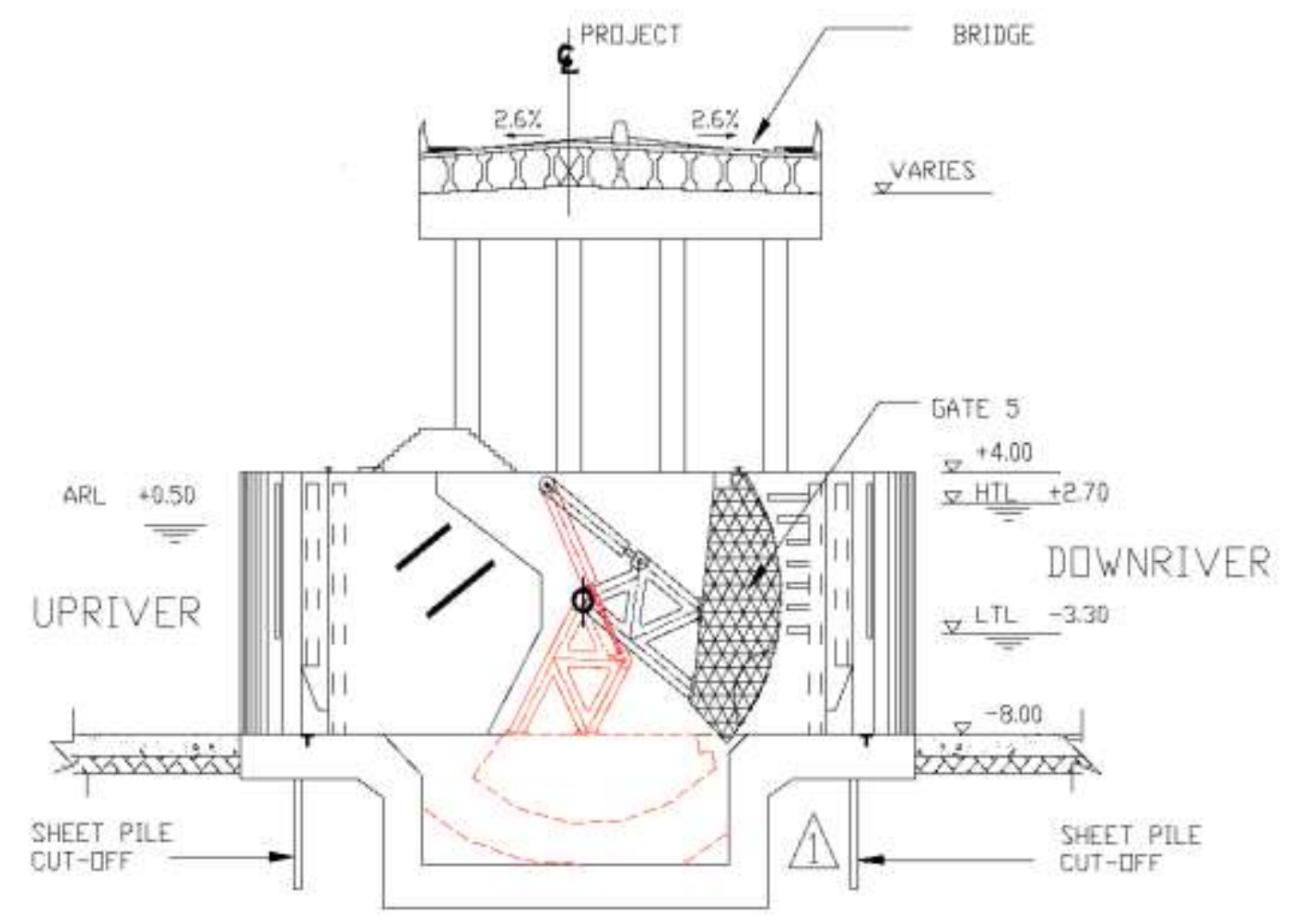

Figure 7: Barrage gate 5 in the close and open (red dotted lines) position (PPES Works)

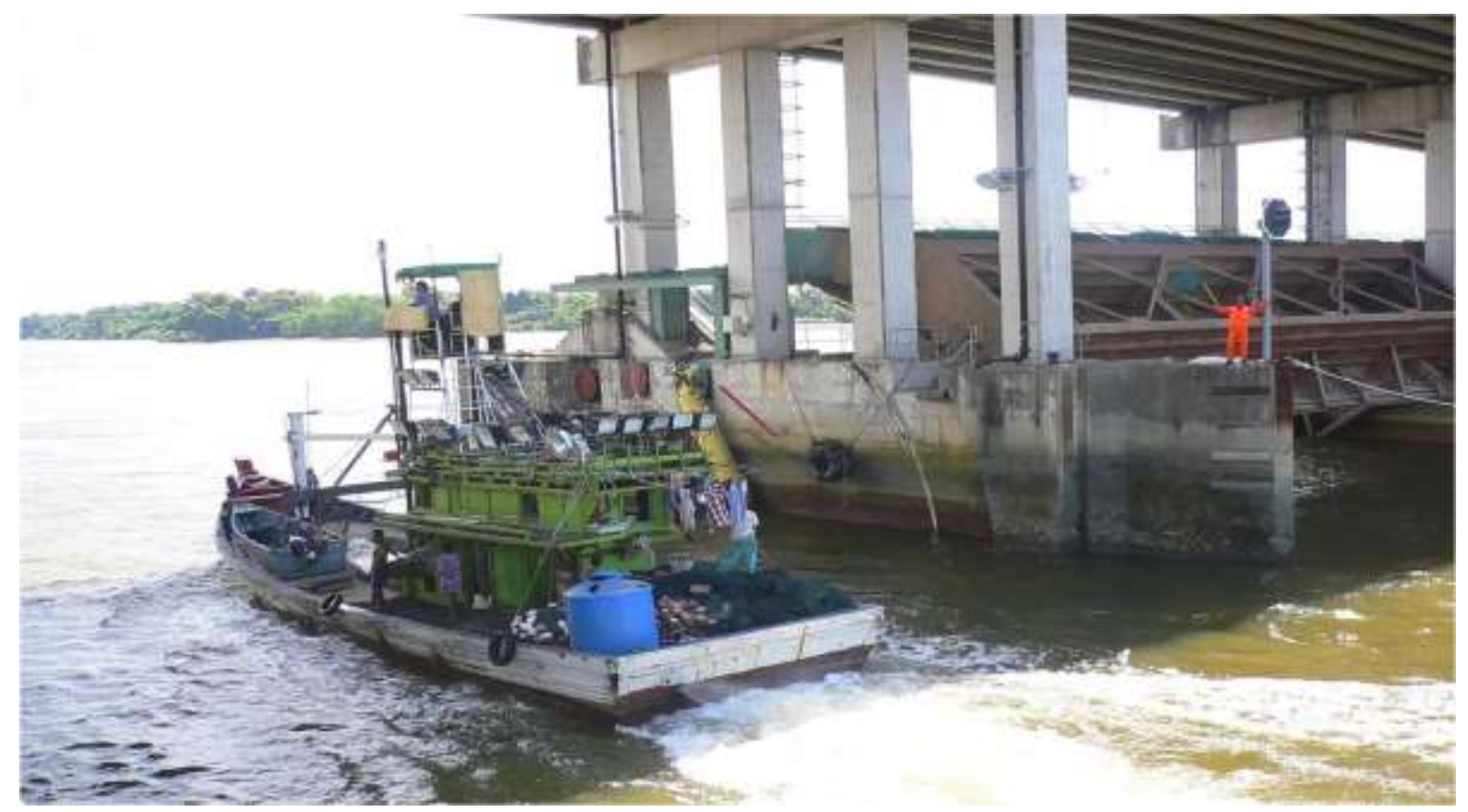

Figure 8: Barrage gates 4 and 5 in the open position with fishing vessel transiting gate 5 Risk aspects of the barrage

During the early days of operation, the barrage gates were kept closed most of the time but the shiplock was operating continuously unless there is a flood scenario. The spillway flaps gates were creating unwanted cross currents to vessels entering the shiplock from upriver. As 
most of the time the water level upstream was maintained around $0 \mathrm{~m} \mathrm{MSL} \mathrm{(Mean} \mathrm{Sea} \mathrm{Level)}$ (8.0 $\mathrm{m}$ at the barrage) cross currents exist upriver and down river. The presence of cross currents (Burt, 2003) is a risk in the maneuvering aspects of vessels entering and leaving the shiplock. Apart from the unfavorable cross currents, the flab gates were experiencing defects in terms twisting of the flab gates and damage to the hydraulic dampers.

Decision was made by the consultants to lock all the flab gates at barrage 1 to 4 to create a conducive environment for all vessels and riverine users upriver of the barrage. This decision has profound effects in the reduction of risk at the barrage and shiplock.

The opening of the gates must be done when the upriver and downriver levels are the same to avoid creating a head difference which will create an unnatural river flow (strong currents) (Hooper \& Austen, 2013) which could result in riverbank slips, parting of vessels mooring lines, damage to landing areas, jetties, and other old weak infrastructures. There were a few occasions in the first two years whereby the barrage gates had to be opened with at least two- or three-meters head difference whereby structural damage to the apron of the barrage gate sill and scouring effects downriver were encountered.

\section{Shipyard Operation}

Above the barrage are four shipyards or slipways where fishing trawlers and smaller vessels are maintained by "up slip" and after repairs they are "down slipped". To enable the shipyards to conduct their operations the operator must raise the water level upstream by opening the barrage gates to raise the water level to a height of $+1.4 \mathrm{~m} \mathrm{MSL}$ or $9.4 \mathrm{~m}$ as their slipway is not long enough to reach the vessels when the level is maintained at the safe level of $0 \mathrm{~m}$ to $+0.5 \mathrm{~m} \mathrm{MSL}$ or $8 \mathrm{~m}$ to $8.5 \mathrm{~m}$ at the barrage. During this operation of flooding in the barrage operators cannot close the barrage gates until the slip yard operator has confirmed that their vessel is firmly chocked and secured at the shipyard. Failure to comply would result in the capsizing of the vessel and injury to the crew or workers.

By raising the upriver water level above the safe level, the barrage operators are creating a flash flood risk scenario in the event of a thunderstorm. The barrage gates cannot be open for the next few hours during this period, until the ebbing tide downriver and upriver are equal. The operator must monitor the status of the catchment area via its 24 telemetry stations (Mah, Hii, et al., 2011; Mah, Putuhena, et al., 2011) and meteorological report during this critical period of about six hours. An illustration of a typical flooding in water level observation on the $7^{\text {th }}$.August 2020 is shown on Figure 9. 


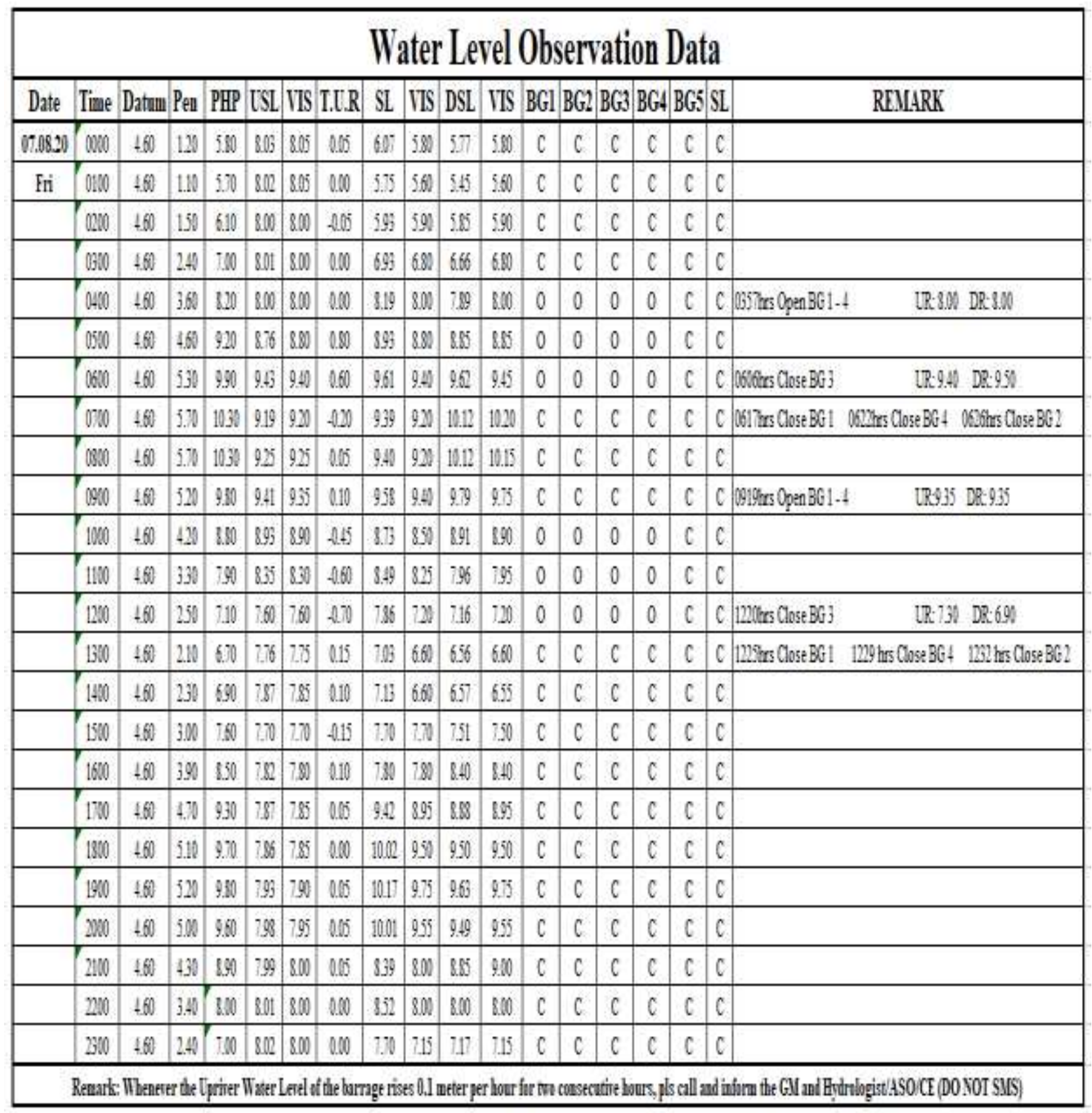

Figure 9: Water level observation (KBM records)

Datum -Chart Datum at the barrage (lowest possible level) $4.6 \mathrm{~m}$ or $-3.4 \mathrm{~m} \mathrm{MSL}$. PenPredicted tide at Pending from the tide tables by the Marine Department Hydrographic unit. PHP- Predicted height at Pending $=$ Chart datum + Predicted height at Pending. USL Upstream level (electronically). Vis- Visual level upstream as per stick gauge at the barrage. TURTopping up rate. SL Shiplock level (electronically). Vis- Visual level in Shiplock as per stick gauge. DSL - Downstream level (electronically). Vis - Visual level as per downriver stick gauge. BG1- Barrage gate 1- Status of gate O open C close. BG2- Barrage gate 2 - Status of gate $O$ open C close. BG3- Barrage gate 3 - Status of gate O open C close. BG4- Barrage gate 4 - Status of gate $O$ open $C$ close. BG5- Barrage gate 5 - Status of gate O open C close. SL - Shiplock Status of gate $\mathrm{O}$ open $\mathrm{C}$ close. 
A graphical representation of the water level upstream and downstream is illustrated graphically on Figure 10. Barrage gates 1-4 were open at $0357 \mathrm{hrs}$., when the upstream and downstream levels were the same i.e., $8.0 \mathrm{~m}$. The water level upstream will rise according to the tide. When the water reached the desired level $(9.4 \mathrm{~m})$ the barrage gates will be closed individually. With the closure of the barrage gates, the upstream level will hover around the desired level. During this period there must not be any heavy torrential rainfall at the catchment area as all the drains in the city are covered since the rainfall cannot be discharged into the river, thus causing an "induced" flood of the city. The barrage operator has been given the task to make the critical decision to cancel the flood in operation at the last minute. However, the water level downriver will rise until the maximum level for that day is reached (10.2 $\mathrm{m})$ and after that period the tide will ebb. (subside).

After flooding in to $9.4 \mathrm{~m}$ upstream (+1.4 m MSL) which is considered a critical level, effort must be made to lower it to a safe level. This can only be achieved during the next cycle of the tide which is about five hours later. The barrage gates must open when the upriver and downriver are at the same as an unnatural river flow will be created if the is a head difference. When the water level reaches the desired water level the barrage gates will be closed separately. The barrage gates must never be closed altogether as the energy from the ebbing tide will create some form of tidal surge especially whereby the level is the same as the receding tide. The barrage gates should never be closed all together especially when it is at mid tide as a "tidal bore" could be created by such an action. The process of closure should be one gate at a time namely, Gate 1, Gate 4, Gate 2 and finally Gate 3. The sequence could be altered if all gates are not close together. It takes about 5 minutes to close a barrage gate and 15 minutes to open. Barrage gate 5 takes about 5 minutes to open and it will lie in the horizontal position when fully open and 15 minutes to close. 


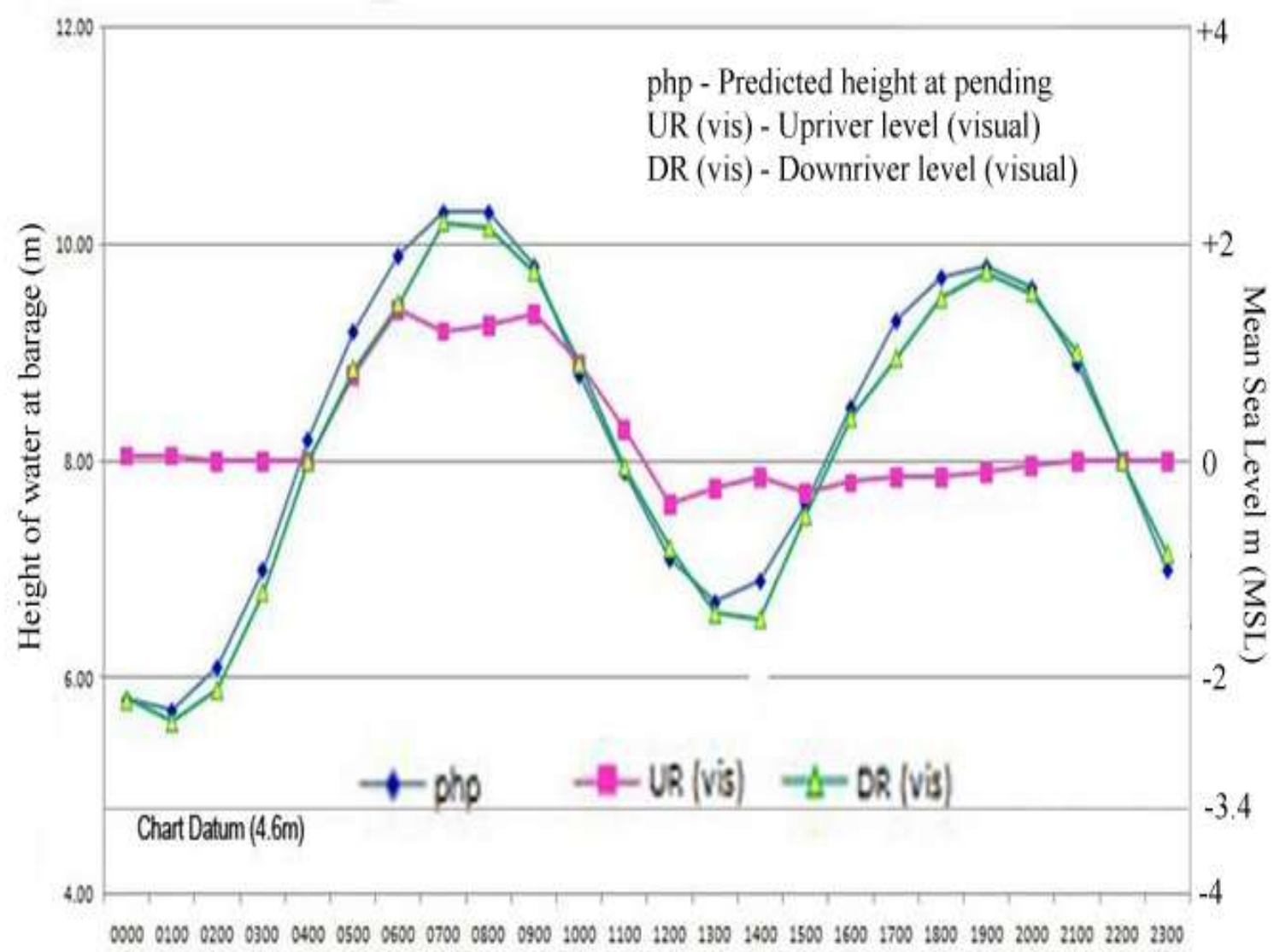

Figure 10: Graphical representation of water level upriver during a flooding in operation

From the graph it is noted that when flood in operations is conducted for the shipyards, the water level upriver will maintained around $9.4 \mathrm{~m}$ or $+1.4 \mathrm{~m} \mathrm{MSL}$ for approximately four hours before the water level could be reduced to a "safe" level. During this period an "induced" flooding could occur due to a torrential heavy downpour as all discharges from the city are covered. An operation flow chart, Figure 11 is prepared to assist the operator to minimize combined fluvial and/or tidal surge flooding. 


\section{OPERATION FLOW CHART TO MINIMISE COMBINED FLUVIAL AND/OR TIDAL SURGE FLOODING}

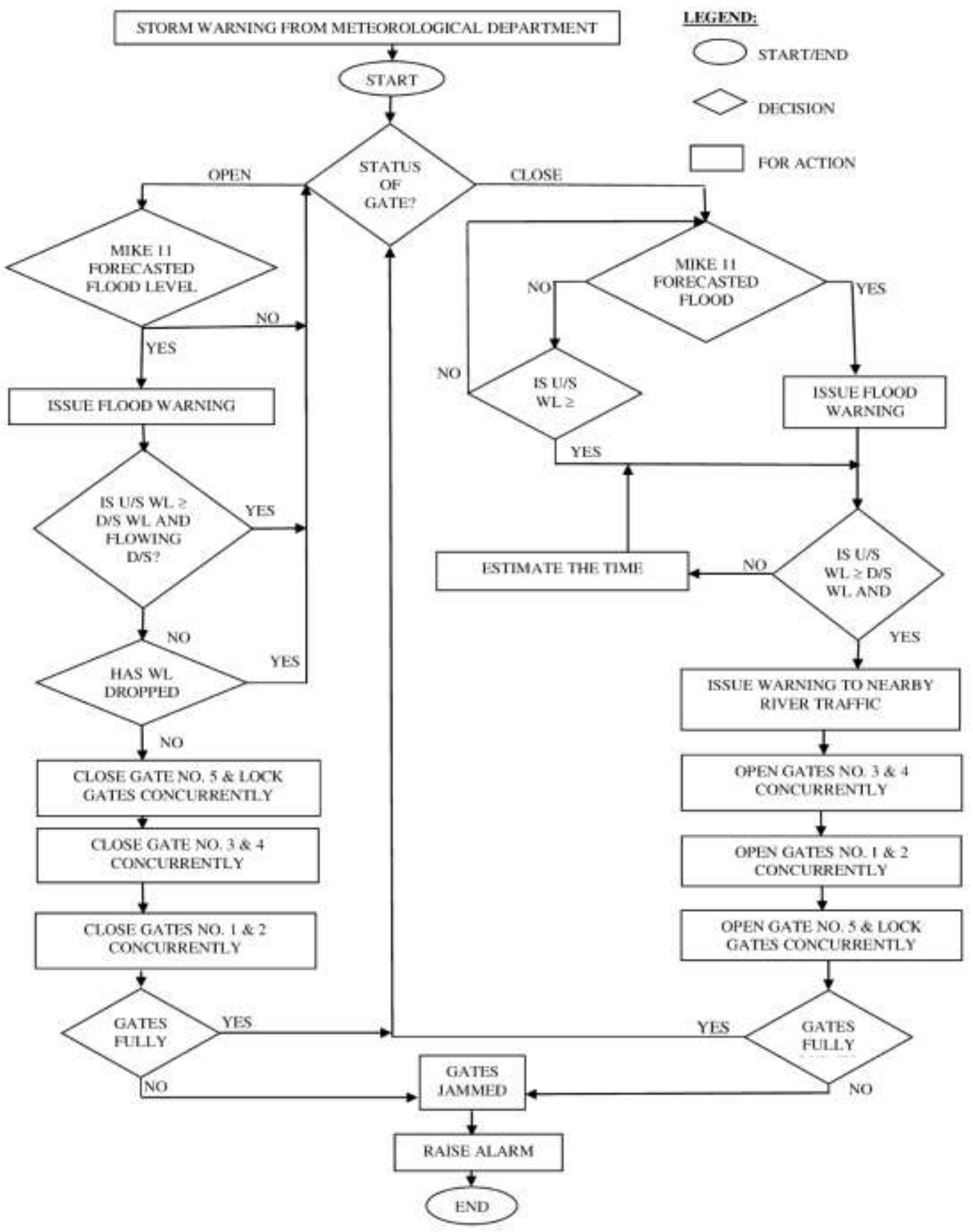

Figure 11: Flow chart of barrage to minimise combined fluvial and/or tidal surge flooding

\section{Operational Aspects of the Barrage}

The Drainage and Irrigation Department Sarawak has established that the major drains in Kuching city will flow into the Sungai Sarawak when the water level is maintained less than 
$+0.5 \mathrm{~m} \mathrm{MSL}$ or $8.5 \mathrm{~m}$ at the barrage. Any water level above this will be critical to the flooding of the city. It is imperative that water level upstream must be maintained below that "safe" level to ensure that no flash floods will occur in the event of a thunderstorm at the catchment area. Figure 12 illustrates an "ideal water level" that should be maintain throughout the year.

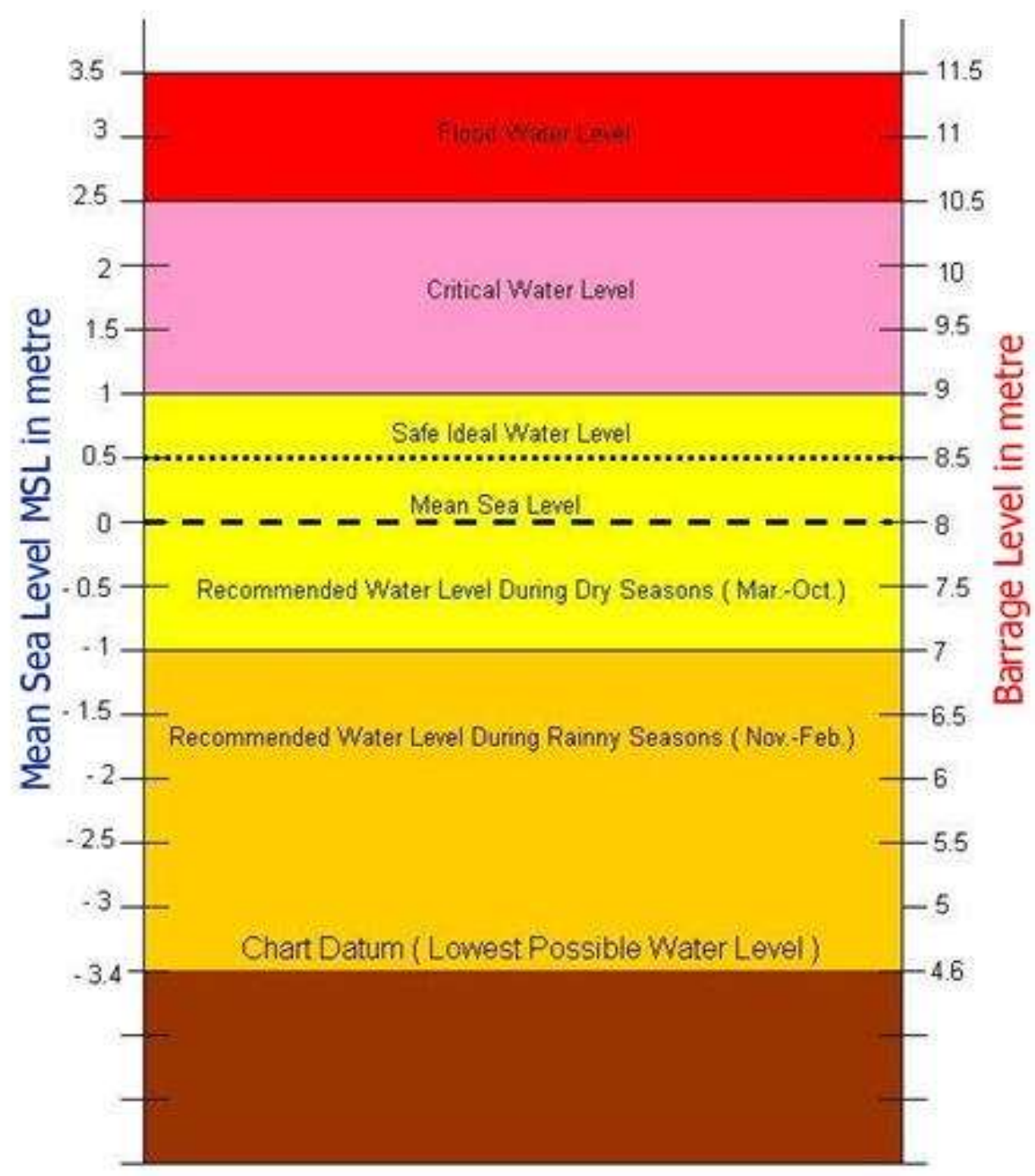

Figure 12: Recommended water levels to maintain during the year

These levels are derived from the first three years of operating the barrage gates to achieve one of the objectives of SSRS. Under normal condition the use of the four barrage gates is sufficient to mitigate any flood scenario. However, the emergency barrage gate five and shiplock gates could be utilized for extra draining out during a high peak flood. These two gates will provide another $50 \%$ extra discharge. When the gates are open there is always a risk of having vessels trying to transit these gates as they cannot wait for transit through the shiplock. During the first two years there were a couple of successful attempts by jet skis and speed boats. To deter them, two $100 \mathrm{~mm}$ diameter mooring ropes were strung across upriver and downriver of the piers. When opening the barrage gates (Adiningrum \& Hadihardaja, 2017), it is not recommended to open it fully as it will take longer to close the barrage gates during an emergency and entice riverine offenders to try going through the barrage gates. 
For flushing operations, the barrage gates must be opened when upriver and downriver are the same as opening with any head difference will create unwanted velocities which might result in slipping of riverbanks, parting of mooring ropes, damage to weak riverine structures such as old jetties, landing steps, capsizing of unattended vessels and a host of other dangerous incidents.

A schedule for the barrage movements is published and announced, most of the public do not take heed. The operators had to use a loud hailer to announce to vessels secured alongside the riverbanks of the intended activity and station approximately five kilometers when the barrage gates are open. There were some incidents of fishing vessels capsizing when the river level is lowered. Unlike the pre barrage days the crew onboard used to monitor the vessels mooring lines when the vessel is alongside but with the barrage the mindset is different.

The "suction" effect is felt once any floating object comes within a kilometer of the barrage gates and increases as it draws nearer to the gates. The operator will sound the general alarm once any floating object approaches the outer barrage zone which is marked by the Lintang buoy. A vigilant watch upstream must be maintained during draining out operations. The barrage enforcement boat is station approximately three nautical miles upriver and will communicate with the control room of any sightings. As the operation is on a twenty-four seven mode of operation, there are at least two personnel in the control room and four ground staff and a technician in attendance during draining out operations. It is established that when the water level tops up 0.1 meter for two consecutive hours there is an indication of pending flood. An operational flow chart for the operators to minimize fluvial or tidal flooding is illustrated in Figure 13. 


\section{Operation Flow Chart to Maintain Water Levels for Fishing Boats and Docking Activities}

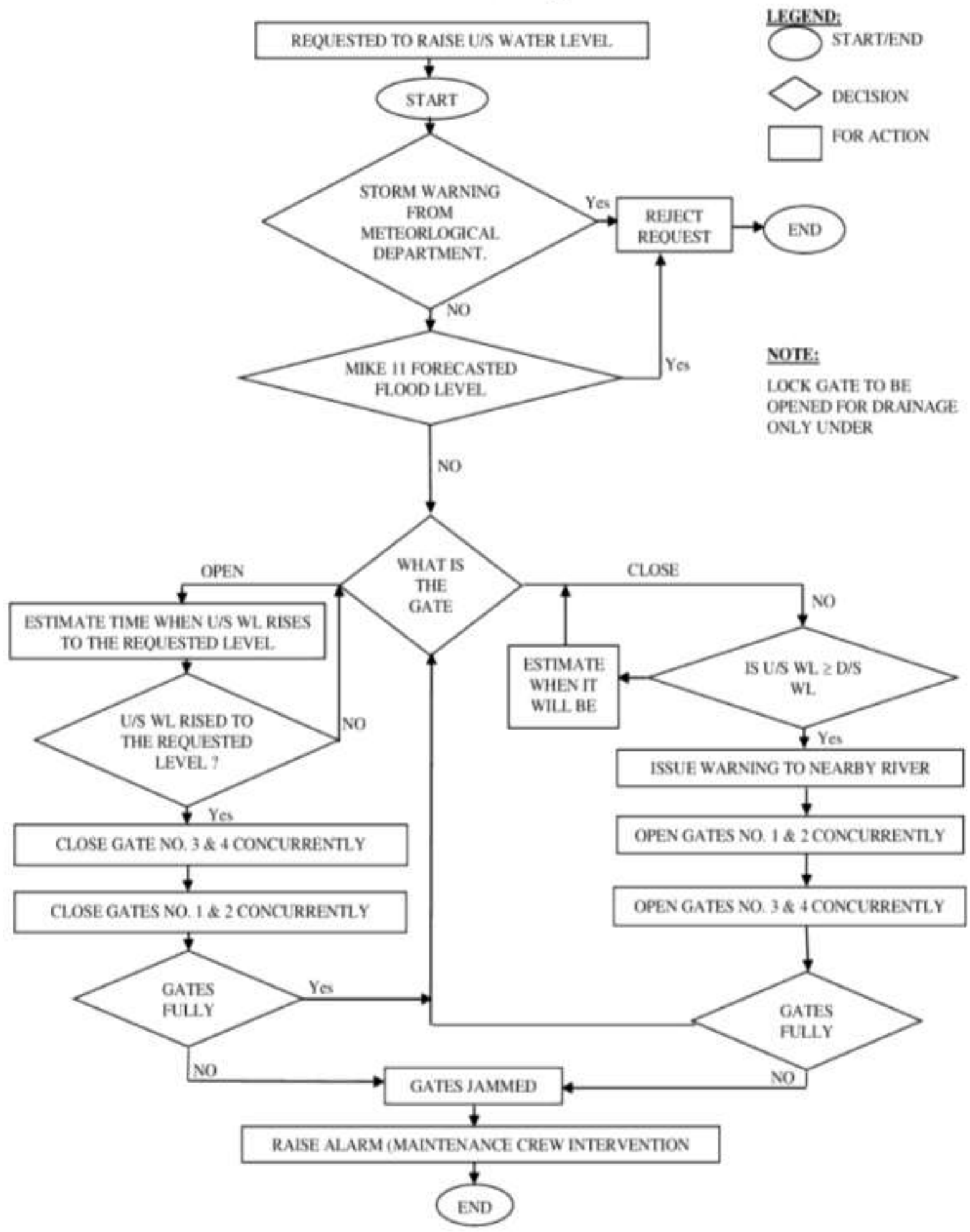

Figure 13: Flow chart to maintain water level for fishing boats and docking activities

\section{Conclusion}

The Sungai Sarawak barrage has eliminated the fortnightly and monthly "nuisance" fluvial flooding of Kuching city and has mitigated the flooding of the city during the high peak risk period of heavy rainfall and tidal intrusion. During the drought season the city is assured of 
raw water supply. In theory certain risk could be identified and mitigated but there is always a new norm for the public to adapt to. Educating the riverine users, stakeholders and the public was the main challenge faced by the operators and a change of mindset.

\section{References}

Adiningrum, C., \& Hadihardaja, I. K. (2017). Reliability analysis for determining performance of barrage based on gates operation. IOP Conference Series: Earth and Environmental Science, 70(1). https://doi.org/10.1088/1755-1315/70/1/012050

Darrien, Y. S. M. (2012). Sarawak River Barrages and Environmental Quality. Universiti Malaysia Sarawak. ISBN: 978-967-5527-36-4 https://www.researchgate.net/publication/303939720

Burt, T. N. (2003). GUIDELINES for the ASSESSMENT and PLANNING of ESTUARINE BARRAGES. Proceedings of the Coastal Engineering Conference. https://doi.org/10.1142/9789812791306_0164

Hooper, T., \& Austen, M. (2013). Tidal barrages in the UK: Ecological and social impacts, potential mitigation, and tools to support barrage planning. Renewable and Sustainable Energy Reviews, 23, 289-298. https://doi.org/10.1016/j.rser.2013.03.001

Kuok, K. K., Harun, S., \& Chiu, P. C. (2011). A review of integrated river basin management for Sarawak River. American Journal of Environmental Sciences, 7(3), 276-285. https://doi.org/10.3844/ajessp.2011.276.285

Mah, D. Y. S., Hii, C. P., Putuhena, F. J., \& Lai, S. H. (2011). River modelling to infer flood management framework. Water SA. https://doi.org/10.4314/wsa.v37i1.64116

Mah, D. Y. S., Putuhena, F. J., \& Lai, S. H. (2011). Modelling the flood vulnerability of deltaic Kuching City, Malaysia. Natural Hazards, 58(3), 865-875. https://doi.org/10.1007/s11069-011-9731-x

Lim, Y. H., \& Sharp, J. J. (2001). Operational aspects of a barrage in extreme climatic conditions. Progress in Water Resources, 50, 349-358.

Mah, D. Y. S., Putuhena, F. J., \& Lai, S. H. (2011). Modelling the flood vulnerability of deltaic Kuching City, Malaysia. Natural Hazards, 58(3), 865-875.

https://doi.org/10.1007/s11069-011-9731-x

Sharp, J. J., \& Howe, L. Y. (2000). The Sarawak River barrage -hydrotechnical and geotechnical aspects. Proceedings of the Institution of Civil Engineers: Water and Maritime Engineering, 142(2), 87-96. https://doi.org/10.1680/wame.2000.142.2.87

Jurutera Jasa (Sarawak) Sdn. Bhd. (2003). Sg. Sarawak Flood Mitigation Options Study.

Director of Marine Department Sarawak. (2020). Sarawak SNP-1. Hourly High \& Low Tide Tables. Prediction for Pending.

Director of Marine Department Sarawak. (2004). Sarawak Nautical Almanac. SAR Charts Catalogue. Senari Port to Kuching. SAR 102.

Kuching Barrage Management Sdn. Bhd. (2020). Hydrographic unit. Water level record. 